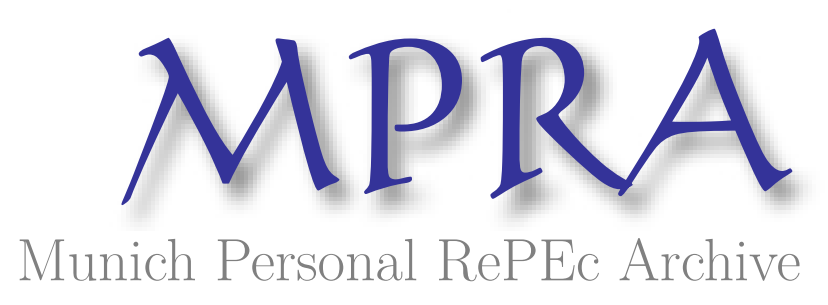

\title{
Profitability and industrial concentration in Pakistan
}

Amjad, Rashid

7 April 1977

Online at https://mpra.ub.uni-muenchen.de/35085/

MPRA Paper No. 35085, posted 30 Nov 2011 12:25 UTC 


\title{
Profitability and Industrial Concentration in Pakistan
}

\author{
by Rashid Amjad*
}

Industrial concentration has been an important political issue in Pakistan. White [1974] recently established a relationship between concentration and the return on capital in a sample of company accounts. This study, based on census material, reexamines the problem with a wider coverage and using the pricecost margin, rather than the return on capital, as the measure of profitability. Concentration and a number of other variables are related to price-cost margins in twenty-five industries between 1965-70. Concentration emerges as the most important explanatory variable but the level of imports and capacity utilisation are also significant.

Industrial assets have shown concentrated ownership in several developing countries [see Hazari, 1966; Mehrav, 1969], especially in earlier industrialisation. However, in Pakistan, it became extreme; it was one of the most controversial aspects of Pakistan's rapid industrial growth in the sixties. Yet it received no detailed investigation. ${ }^{1}$ The only basis for opinions about it was Haq's ${ }^{2}$ famous statement that twenty-two families own eighty-seven per cent of the banking and insurance and sixty-six per cent of the industrial assets [Dawn, 25th April, 1968].

Recently, however, some attempts have been made to investigate this concentration [Shibli, 1972; Amjad, 1974; White, 1974] in both industry and finance, but only White has also looked into the impact of concentration on profitability by industries. My aim (like White's ) is to examine the relationship between concentration and profitability, but instead of White's profitability measure based on balance sheets of quoted companies, I use the price-cost margin, based on the Census of Manufacturing Industries [Central Statistical Office, Govt. of Pakistan].

Part I assesses White's model and findings. He reads more into his results than his findings justify, and his industry profitability variable in certain cases applies to too few firms to be representative of that industry. Part II looks at the effect of concentration and other variables, such as competing imports and capacity utilisation on profitability as measured by price-cost margins.

\section{PART I: WHITE'S MODEL AND EMPIRICAL FINDINGS}

In his model [for details see White, 1974a or 1974b] White introduced

\footnotetext{
* The author is Assistant Professor of Economics at Punjab University, Lahore and is at present doing research at Queens' College, Cambridge. He would like to thank Professor R. R. Neild for his guidance and detailed comments on the whole paper. He is also grateful to Dr. R. P. Smith, A. Saith, A. Sen, Meekal Ahmed, A. K. Ghose and M. Hossain for their very helpful comments on different sections of the paper.
} 
two other important variables which one would expect, a priori, in Pakistan, to have considerable effect on profitability, namely the dependence of an industry on imported raw materials and the protection given to the industry from foreign competition.

In the case of the former, profitability according to White would be affected both by the terms on which the firms could get imported raw materials as well as their ability to get them freely. If a high tariff was levied on imported raw materials it would lower the rate of effective protection. Similarly if licensing arrangements for imports of these raw materials were very stringent it would mean that output would be limited to a level below the profit maximising one. Since there was no direct measure available for these two effects, White used a proxy, the degree of capacity utilisation. This, however, cannot be a very good proxy for every industry or for all periods, as capacity utilisation of an industry is influenced by a number of other factors besides its dependence on imported raw material [see Winston, 1968] and applies much more to those industries with high dependence on imported raw materials. Also this variable would not be able to pick up the effect of the 'terms' on which these raw materials are made available.

The /second important variable in White's model was competing imports. A number of studies on Pakistan [Pal, 1964; Lewis, 1970] have shown that the protection given to a domestic industry is determined not by the extent of the tariff but by the quantitative restriction on imports. For the variable measuring the stringency of licensing of competitive imports White used the figures given by Lewis and Guisinger [1971] to measure the difference between domestic price and the c.i.f. import price for the various industries for the year 1963/64.

\section{Result of White's Model}

White tested his model using cross-section data primarily from 1964 and 1965 and used a measure of industry profitability based on firms listed on the Karachi Stock Exchange. Because of the limitation of the type of firms listed on the Karachi Stock Exchange and the limited number of industries listed by Lewis and Guisinger the sample was restricted to 17 industries. $^{3}$

The results of his regression analysis were as follows:

$$
\begin{aligned}
& \mathrm{P}=-0.37+0.16 \mathrm{C}^{\mathrm{c}}+0.08 \mathrm{~W}^{\mathrm{b}}+1.19 \mathrm{CU}-0.81 \mathrm{CU}^{2} \\
& (0.68)(1.74) \quad(2.25) \quad(0.73) \quad(0.70) \\
& R^{2}=0.42
\end{aligned}
$$

b: significant at the 5 per cent level.

c: significant at the 10 per cent level.

Note: Figures in parentheses are t-ratios.

Where $\mathbf{P}=$ industry profitability ratio, measured as the weighted average of net pre-tax profits to net worth for 1964 and 1965 for firms quoted on the Karachi Stock Exchange.

$\mathrm{C}=$ Four-firm concentration ratio. 
$\mathrm{W}=$ Average difference between domestic price and imported price.

and $\mathrm{CU}=$ capacity utilisation for each industry.

White concluded from his result 'that there seems to be a positive relationship between profit rates, industrial concentration and import licensing stringency'. According to him 'the sample is small, the data are spotty, the results are not wholly satisfactory, but the basic tendencies seem to be present' [White, 1974b: 146].

\section{Weaknesses of White's Results}

Although White was cautious in the findings of his result, he seemed to have ignored the rather obvious fact that most of the coefficients in his regression equation were not significantly different from zero (the $t$ ratios were too low). Only the indicator showing the difference between domestic and world price (to measure the extent of protection given to the domestic industry) was significant at the five per cent level (and here its coefficient was very low indeed) and concentration was only significant at the ten per cent level. The capacity utilisation variable was not significant at all although White had interpreted the coefficients of this variable 'as most reasonable' [White, 1974b: 146] as they indicated that maximum profits were reached when capacity utilisation was between 70 and 75 per cent.

The major problem we found concerned White's indicator of profitability which appeared in a number of cases to be seriously unrepresentative of the industry. This problem arose because the number of quoted firms, on which his profitability indicator was based, were either too few to be representative of the industry or belonged to a specific industry which was unrepresentative of the industry group used by him. Cases where the sample of quoted firms was not representative of the industry group and also accounted for a very small portion of total production (between seven and twenty-five per cent) were metal products, nonmetallic minerals except cement, electrical machinery, art and art silk industry, vegetable ghee and non-electrical machinery. In the case of six out of the seventeen industries covered in his sample, therefore, the profitability ratios could hardly be taken as representative of the industry in the large-scale manufacturing sector.

\section{PART II: PRICE-COST MARGINS AND CONCENTRATION -}

W. PAKISTAN 1965-70

Since the major drawback with White's study was its limited coverage of the profitability indicator we decided to use an alternative measure of profitability, the price-cost margin. This indicator (defined below) has been used in a number of studies to test the relationship between profitability and concentration [See Schwartzmen, 1959; Collins \& Preston, 1968; Holterman, 1973 and Khalizadeh, 1974; Sawhney and Sawhney, 1973.]

The data on which the price-cost margin is based, the Census of Manufacturing Industries, were only available for W. Pakistan for the 
years between 1965 and 1970 and this meant that the study had to be limited only to W. Pakistan. To take this factor into account jute, tea, paper and paper product industries were excluded, as the major portion of production in these industries was in E. Pakistan and W. Pakistan was dependent on inter-wing imports. ${ }^{4}$

\section{Profit Measure}

The price-cost margin was calculated by subtracting both direct and indirect costs from gross sales.

PC $=$ Gross Value of Output ${ }^{*}$ - Employment Cost - Industrial Costs** - depreciation-rent-interest - advertising - other overhead costs/Gross Value of Output*

* Less indirect taxes.

** Raw material and fuel and electricity costs.

Our measure of the price-cost margin by excluding fixed costs takes into account the criticism [see Benishay, 1967; Ornstein, 1975] that differences across industries of this measure could be due to differences in capital-output ratio alone.

The basic source from which the price-cost margins were calculated was the Census of Manufacturing Industries and these were available for $1965 / 66,1966 / 67,1967 / 68$ and 1969/70. For each industry besides calculating the price-cost margin for each year we also took the average of all the four years.

\section{Concentration Ratios}

Our measure of concentration is the share of the four largest firms of total sales or output of the industry in 1968. The basic data used for the estimation of the concentration ratios of different industries was the Directory of Industrial Establishments [Investment Promotion and Supplies Department, Govt. of Pakistan], together with Fazili, [1969,] and Jafri, [1969].

\section{Sample of Industries Covered}

Our study covers 25 industries except for 1965/66 when the petroleum and petroleum products industry was not in production. Each of these industries contributed at least one per cent of total value added in the large-scale manufacturing sector in 1969/70. The sample accounted for 80 per cent of the value added of the large-scale manufacturing sector of W. Pakistan in $1969 / 70$.

\section{Model}

The relationship between price-cost margin and concentration was tested in both the linear and non-linear form as follows:

$$
\begin{gathered}
(\mathrm{PC})_{\mathrm{i}}=\alpha+\mathrm{b}_{1}\left(\mathrm{CR}_{4}\right)_{\mathrm{i}}+\mathrm{b}_{2}(\mathrm{~K} / \mathrm{O})_{\mathrm{i}}+\mathrm{e} \\
\log (\mathrm{PC})_{\mathrm{i}}=\alpha+\mathrm{b}_{1} \log \left(\mathrm{CR}_{4}\right)_{\mathrm{i}}+\mathrm{b}_{2} \log (\mathrm{K} / \mathrm{O})_{\mathrm{i}}+e
\end{gathered}
$$


Where $(P C)_{i}=$ Measures of the price-cost margin in the ith industry.

$\left(\mathrm{CR}_{4}\right)_{\mathrm{i}}=$ Four-firm concentration ratio of the ith industry.

$(\mathrm{K} / \mathrm{O})_{\mathrm{i}}=$ Capital-output ratio of the ith industry.

$\mathrm{e}=$ error term.

The capital-output ratio was included in the model to see to what extent high absolute capital requirements, reflected in high capitaloutput ratios, would constitute barriers to entry and further strengthen the relationship between price-cost margins and concentration. The capital-output ratio was calculated by dividing the book value of fixed assets by the value of production.

TABLE 1

RESULT OF REGRESSION ANALYSIS: PRICE-COST MARGINS, CONCENTRATION AND CAPITAL-OUTPUT RATIOS*

\begin{tabular}{|c|c|c|c|c|c|c|}
\hline $\begin{array}{l}\text { Dependent } \\
\text { Variable }\end{array}$ & $\begin{array}{c}\text { Concentra- } \\
\text { tion Ratio } \\
\left(C R_{4}\right)\end{array}$ & $\begin{array}{c}\text { Capital- } \\
\text { Output Ratio } \\
(K / O)\end{array}$ & $\begin{array}{l}\text { Concentra- } \\
\text { tion Ratio } \\
\log \left(C R_{4}\right)\end{array}$ & $\begin{array}{c}\text { Capital- } \\
\text { Output Ratio } \\
\log (K / O)\end{array}$ & $\begin{array}{c}\text { Constant } \\
\text { Term }\end{array}$ & $R^{2}$ \\
\hline \multicolumn{7}{|l|}{$1965 / 66^{* *}$} \\
\hline (1) PC & $\begin{array}{c}0 \cdot 16^{\mathrm{b}} \\
(2 \cdot 091)\end{array}$ & $\begin{array}{l}-1.94 \\
(0.6663)\end{array}$ & & & $12 \cdot 85$ & $0 \cdot 17$ \\
\hline (2) $\log P C$ & & & $\begin{array}{c}0.44^{a} \\
(2 \cdot 815)\end{array}$ & $\begin{array}{l}0.09 \\
(0.6261)\end{array}$ & $1 \cdot 23$ & 0.36 \\
\hline \multicolumn{7}{|l|}{$1966 / 67$} \\
\hline (1) PC & $\begin{array}{c}0 \cdot 18^{\mathrm{b}} \\
(2 \cdot 502)\end{array}$ & $\begin{array}{l}-0.63 \\
(0.217)\end{array}$ & & & $11 \cdot 24$ & 0.27 \\
\hline (2) $\log P C$ & & & $\begin{array}{c}0 \cdot 28^{\mathrm{b}} \\
(2 \cdot 151)\end{array}$ & $\begin{array}{c}0.14 \\
(1 \cdot 155)\end{array}$ & 1.94 & 0.35 \\
\hline $\begin{array}{l}196 \% 1 / 08 \\
\text { (1) PC }\end{array}$ & $\begin{array}{c}0.21^{a} \\
(3 \cdot 087)\end{array}$ & $\begin{array}{c}-4.04 \\
(0.882)\end{array}$ & & & 11.94 & 0.31 \\
\hline (2) $\log P C$ & & & $\begin{array}{c}0.41^{\mathrm{a}} \\
(2.943)\end{array}$ & $\begin{array}{c}0.06 \\
(0.398)\end{array}$ & 1.42 & 0.36 \\
\hline $1969 / 70$ & & & & & & \\
\hline (1) PC & $\begin{array}{c}0 \cdot 33^{a} \\
(4 \cdot 414)\end{array}$ & $\begin{array}{l}-1 \cdot 32 \\
(0.346)\end{array}$ & & & 7.82 & 0.50 \\
\hline (2) $\log P C$ & & & $\begin{array}{c}0 \cdot 52^{\mathrm{a}} \\
(4 \cdot 216)\end{array}$ & $\begin{array}{l}0.07 \\
(0.6387)\end{array}$ & $1 \cdot 19$ & 0.51 \\
\hline $\begin{array}{l}\text { Av: } 4 \text { Years } \\
\text { (1) PC }\end{array}$ & $\begin{array}{c}0 \cdot 22^{a} \\
(4 \cdot 226)\end{array}$ & $\begin{array}{c}-0.89 \\
(0.322)\end{array}$ & & & 2.45 & 0.49 \\
\hline (2) $\log P C$ & & & $\begin{array}{c}0 \cdot 41^{\mathrm{a}} \\
(4 \cdot 131)\end{array}$ & $\begin{array}{c}0.12 \\
(1 \cdot 180)\end{array}$ & 1.52 & 0.57 \\
\hline
\end{tabular}

* 25 industries

** 24 industries (excludes petroleum)

Note: Figures in parentheses are t-ratios. a: significant at the 1 per cent level. b: significant at the 5 per cent level. c: significant at the 10 per cent level.

\section{Results}

The results of the regression analysis are given in Table 1 for the individual years as well as for the average of the four years. There is a significant relationship between price-cost margins and concentration for the model tested. The regression coefficient of the concentration 


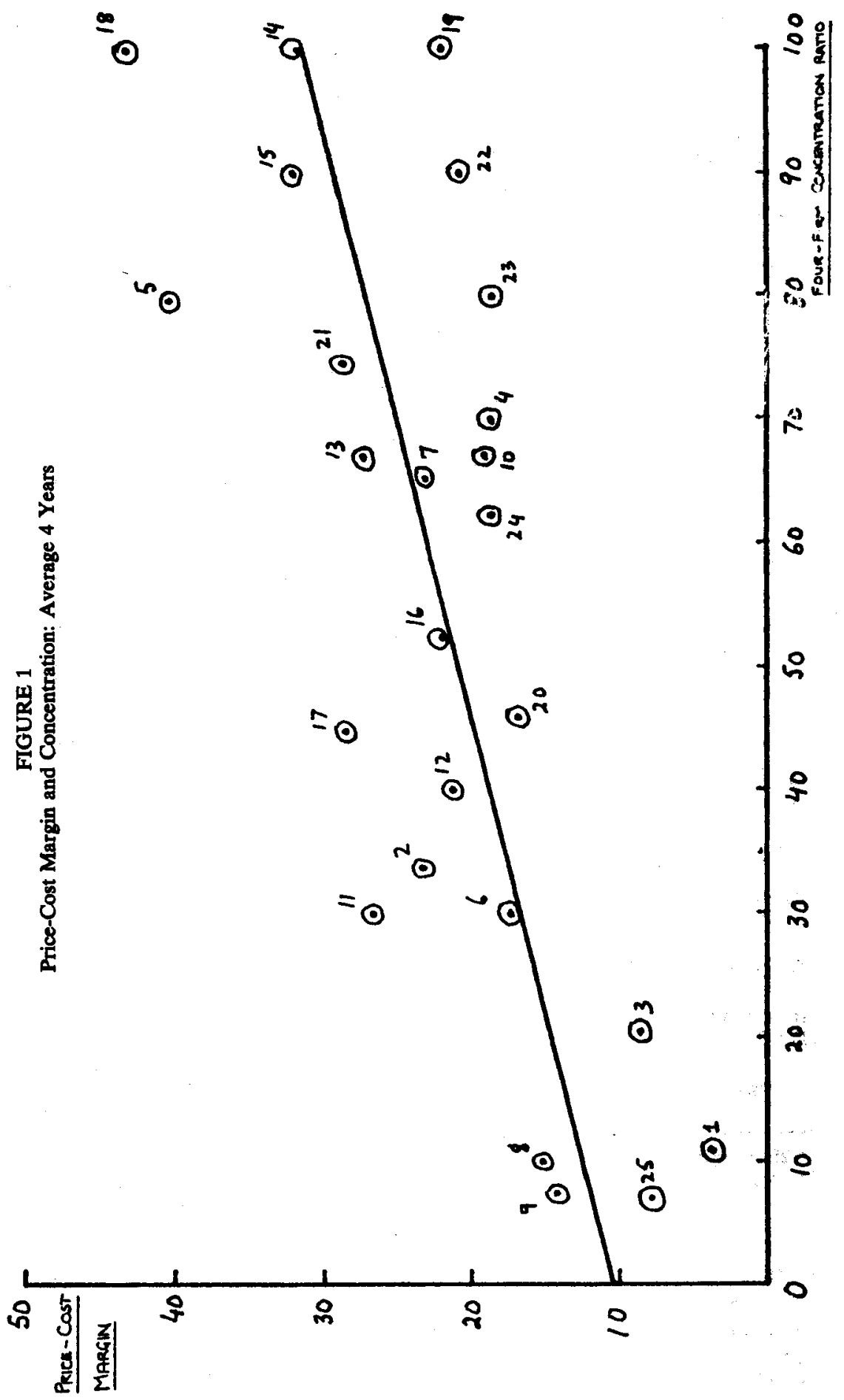


Key to Figure 1

1. Grain Milling

2. Sugar

3. Edible Oils

4. Drinks

5. Cigarettes

6. Cotton Spinning

7. Wool Spinning

8. Silk and Art Silk

9. Dyeing and Bleaching
10. Rubber Footwear

11. Books and Periodicals

12. Tanning and Leather

13. Cement

14. Tyres and Tubes

15. Fertiliser

16. Paints and Varnishes

17. Pharmaceuticals

18. Prod. of Petroleum
19. Acids, Alkalies and Salts

20. Iron and Steel

21. Motors, Generators and Transformers

22. Communication Equipment \&

23. Mechanical Vehicle

24. Engines and Turbines

25. Cotton Ginning

\section{TABLE 2}

RESULT OF SIMPLE REGRESSION ANALYSIS: PRICE-COST MARGNSS WTTH CAPITAL OUTPUT RATIO

\begin{tabular}{lccr}
\hline $\begin{array}{l}\text { Dependent } \\
\text { Variable }\end{array}$ & $\begin{array}{c}\text { Regression Coefficient } \\
\text { for K/O Variable }\end{array}$ & Constant Term & $\boldsymbol{R}^{2}$ \\
\hline $1965-66$ & 0.49 & 19.48 & 0.001 \\
PC & $(0.173)$ & & \\
$1966-67$ & 3.30 & 18.02 & 0.006 \\
PC & $(1.210)$ & & \\
$1967-68$ & 2.40 & 20.2 & 0.01 \\
PC & $(0.508)$ & & \\
$1969-70$ & 6.68 & 21.63 & 0.06 \\
PC & $(1.240)$ & & \\
Av: 4 Years & $4.56^{c}$ & 19.1 & 0.08 \\
PC & $(1.419)$ & & \\
\hline
\end{tabular}

c: significant at the 10 per cent level.

Note: Figures in parenthesis are t-ratios.

ratio variable is significant at less than the five per cent level for all years and at less than one per cent level for $1967 / 68$ and 1969/70 and the average of the four years. Given the fact that in certain industries the price-cost margins were subject to wide fluctuations, the result for the average of the four years is the most representative of the relationship between price-cost margins and concentration, and here the regression coefficient is significant at the one per cent level (Fig. 1). Our results also further shows that using the non-linear log relationship does not significantly change the result or add greatly to the explanatory power of the model, with the exception of $1965 / 66$ where the concentration ratio variable is slightly more significant.

The regression coefficient of the capital-output ratio was not significant for any of the four years or for the average of the four years. Given the fact that there does exist a slight correlation between capital-output ratio and concentration (simple correlation coefficient $r$ is between 0.40 to 0.54 for the different years) we regressed PC with K/O ratio alone. The coefficient of the $K / O$ ratio was positive but the result was not significant for any of the four years except at the ten per cent level for the average of the four years (see Table 2). This indicates that capital 
intensity of the industry as reflected in the $\mathrm{K} / \mathrm{O}$ ratio was not significantly related with the profitability measure which excludes fixed costs.

In order to see if there were any significant differences in the relationship between price-cost margins and concentration for the different years (i.e. whether the intercept or the slope changed significantly between the years) we pooled the data for the four years and ran the regression with dummy variables for the different years in the form given below:

$$
\begin{aligned}
& \mathrm{PC}=12.53-1.311 \alpha_{2}-1.261 \alpha_{3}-4.906 \alpha_{4}+0.14 \mathrm{CR}_{4}^{\mathrm{b}}+
\end{aligned}
$$

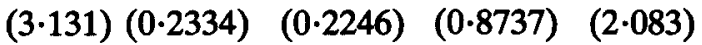

$$
\begin{aligned}
& 0.03 \mathrm{CR}_{4} \alpha_{2}+0.05 \mathrm{CR}_{4} \alpha_{3}+0.09 \mathrm{CR}_{4} \alpha_{4}^{\mathrm{b}} \\
& (0.8401) \quad(0.5369) \quad(1.996) \\
& \mathbf{R}^{2}=0 \cdot 36
\end{aligned}
$$

a: significant at the 1 per cent level.

b: significant at the 5 per cent level.

Note: Figures in parenthesis are t-ratios.

Where $\mathrm{PC}=$ Measures of the price-cost margin.

$\mathrm{CR}_{4}=$ Four-firm concentration ratio

$\alpha_{i}=1$ for an observation in year $i, i=2,3,4$.

$=0$ otherwise.

The results show that there was no significant differences for the intercept in the different years for both our indicators of the price-cost margin. In the case of the slope only in the last year is the relationship significantly different at the five per cent level. One possible reason for this was that some of the capital goods and intermediate goods industries, where the concentration ratio was high and which had been suffering from low profit levels, were able to improve their performance either because of a slightly higher capacity utilisation or having overcome some of the initial problems in the running of these industries. (This was especially true for example of the chemical industry.)

\section{Impact of Foreign Competition on Price-Cost Margins}

In White's model, discussed earlier, the other key variable which influenced profitability was the degree of protection given to the domestic industry from foreign competition. In order to see the effect of foreign competition and the level of protection afforded to the domestic industry, on price-cost margins we tested the model in the following form:

$$
P C=\alpha+b_{1} C R_{4}+b_{2} P
$$

where $\mathrm{PC}$ is the price-cost margin, $\mathrm{CR}_{4}$ is the four-firm concentration ratio and $P$ is the level of protection.

For the level of protection we used all three measures calculated for 1963/64 by Lewis and Guisinger [1971], namely for each industry the 
difference between the domestic and c.i.f. import price, the effective rate of protection and the effective rate of protection from all sources for 18 of the 25 industries for which they were given. Since protection would vary considerably with changes in government import policies (and these were very frequent) we ran the model only for $1965 / 66$, the year nearest to their measure of protection. The results were not significant for any of the three measures of protection and the sign of the regression coefficient was negative.

There can be two main reasons for not expecting any association between Lewis and Guisinger's measurement of protection and domestic profitability. The first is that the measures of protection are extremely inaccurate. This could arise not only because of the inherent difficulties in measuring the rate of protection but also the lines followed by them make it extremely difficult to place much confidence in their calculations. ${ }^{5}$ Secondly, effective protection need not be reflected in profitability differences amongst industries because the 'efficiency' of the domestic industry when compared with foreign competitors could show considerable variations. Therefore, a domestic industry may enjoy high protection relative to 'world prices' and still earn low profits, if industrial costs are high, because of technical inefficiencies like unskilled labour, low capacity utilisation and frequent stoppages (of which the chemical industry is the best example because of frequent electricity failures). This could also explain to some extent the negative sign of the regression coefficient.

Since there was no other study available besides Lewis which measures the rate of effective protection, and since in White's model the check on monopoly power is the amount of competitive imports as a proportion of domestic sales, we decided to test the relationship between price-cost margins and competing imports in the following two forms:

$$
\begin{aligned}
& (P C)_{i}=\alpha+b_{1}\left(C R_{4}\right)_{i}+b_{2}(K / O)_{i}-b_{3}(M)_{i}+e \\
& (P C)_{i}=\alpha+b_{i}\left(C R_{4}\right)_{i}+b_{2}(K / O)_{i}-b_{3}\left(M_{D}\right)_{i}+e
\end{aligned}
$$

Where $(\mathrm{PC})_{\mathrm{i}}=$ Price-cost margin of the ith industry.

$\left(\mathrm{CR}_{4}\right)_{\mathrm{i}}=$ Four-Firm Concentration ratio of the ith industry.

$(\mathrm{K} / \mathrm{O})_{\mathrm{i}}=$ Capital-output ratio of the ith industry.

$(M)_{i}=$ Competing imports i.e. imports as a percentage of total domestic supply.

$\left(M_{D}\right)_{i}=$ Dummy variable for competing imports of the ith industry i.e. $M_{D}=0$ when imports are less than 20 per cent of domestic sales otherwise $M_{D}=1$. $\mathrm{e}=$ error term.

The results are given in Table 3. In the first case the import variable has the negative sign for four of the five cases but is only significant in two cases-at the five per cent level for $1965 / 66$ and at the ten per cent level for the average of the four years. However, when we use the dummy variable for competing imports, and divided the industries into two different categories-those where imports are less than twenty per 
TABLE 3

RESULT OF REGRESSION ANALYSIS: IMPACT OF MMPORTS ON DOMESTIC PROFITABILITY

\begin{tabular}{|c|c|c|c|c|c|c|}
\hline $\begin{array}{l}\text { Dependent } \\
\text { Variable } \\
(P C)\end{array}$ & $\begin{array}{c}\text { Concentra- } \\
\text { tion Ratio } \\
\left(C R_{4}\right)\end{array}$ & $\begin{array}{c}\text { Capital- } \\
\text { Output Ratio } \\
(K / O)\end{array}$ & $\begin{array}{l}\text { Competing } \\
\text { Imports } \\
\text { (M) }\end{array}$ & $\begin{array}{c}\text { Dummy for } \\
\text { Imports } \\
\left(M_{D}\right)\end{array}$ & $\begin{array}{l}\text { Constant } \\
\text { Term }\end{array}$ & $R^{2}$ \\
\hline \multicolumn{7}{|l|}{$1965 / 66$} \\
\hline & $\begin{array}{c}0.20^{\mathrm{a}} \\
(3.237)\end{array}$ & $\begin{array}{l}-3 \cdot 67 \\
(1 \cdot 327)\end{array}$ & $\begin{array}{c}-0.23^{b} \\
(2.298)\end{array}$ & - & $11 \cdot 53$ & 0.35 \\
\hline (2) & $\begin{array}{c}0.24^{a} \\
(2 \cdot 605)\end{array}$ & $\begin{array}{c}-2.97 \\
(1.018)\end{array}$ & - & $\begin{array}{c}-7 \cdot 58^{c} \\
(1.483)\end{array}$ & $12 \cdot 11$ & 0.26 \\
\hline \multicolumn{7}{|l|}{$1966 / 67$} \\
\hline (1) & $\begin{array}{c}0.21^{*} \\
(2.591)\end{array}$ & $\begin{array}{c}-0.76 \\
(0.259)\end{array}$ & $\begin{array}{l}-0.08 \\
(0.876)\end{array}$ & - & $10 \cdot 89$ & 0.29 \\
\hline (2) & $\begin{array}{c}0.23^{\mathrm{a}} \\
(2.946)\end{array}$ & $\begin{array}{c}-0.69 \\
(0.243)\end{array}$ & - & $\begin{array}{l}-6.31^{c} \\
(1 \cdot 450)\end{array}$ & 10.46 & 0.33 \\
\hline \multicolumn{7}{|l|}{$1967 / 68$} \\
\hline (1) & $\begin{array}{c}0 \cdot 21^{a} \\
(2 \cdot 580)\end{array}$ & $\begin{array}{l}-4.23 \\
(0.895)\end{array}$ & $\begin{array}{c}0.03 \\
(0.122)\end{array}$ & - & $12 \cdot 10$ & $0 \cdot 31$ \\
\hline (2) & $\begin{array}{c}0 \cdot 22^{\mathrm{a}} \\
(2 \cdot 780)\end{array}$ & $\begin{array}{c}-3.84 \\
(0.815)\end{array}$ & - & $\begin{array}{c}-1.48 \\
(0.514)\end{array}$ & 11.65 & 0.31 \\
\hline $\begin{array}{l}1969770 \\
(1)\end{array}$ & $\begin{array}{c}0 \cdot 37^{a} \\
(4 \cdot 226)\end{array}$ & $\begin{array}{l}-1.36 \\
(0.308)\end{array}$ & $\begin{array}{l}-0.11 \\
(0.973)\end{array}$ & - & $7 \cdot 04$ & 0.52 \\
\hline (2) & $\begin{array}{c}0.40^{\mathrm{a}} \\
(4.639)\end{array}$ & $\begin{array}{c}-1.18 \\
(0.274)\end{array}$ & & $\begin{array}{c}-7 \cdot 79^{c} \\
(1 \cdot 501)\end{array}$ & 6.47 & 0.55 \\
\hline $\begin{array}{l}\text { Av: } 4 \text { Years } \\
\text { (1) }\end{array}$ & $\begin{array}{c}0.27^{a} \\
(4 \cdot 629)\end{array}$ & $\begin{array}{l}-0.81 \\
(0.303)\end{array}$ & $\begin{array}{c}-0.12^{c} \\
(1.669)\end{array}$ & - & 9.92 & 0.55 \\
\hline (2) & $\begin{array}{c}0 \cdot 28^{a} \\
(5 \cdot 104)\end{array}$ & $\begin{array}{l}-1.03 \\
(0.406)\end{array}$ & - & $\begin{array}{l}-7.06^{b} \\
(2.251)\end{array}$ & $9 \cdot 72$ & 0.59 \\
\hline
\end{tabular}

a: significant at the 1 per cent level.

b: significant at the 5 per cent level.

c: significant at the 10 per cent level.

Note: Figures in parentheses are t-ratios.

cent and those with more-the results are slightly improved compared to the first form of the model. The sign of the import variable is negative in all cases as the model predicts and is significant in four of the five cases.

It could, however, be possible that what one has to see is not just the level of imports, per se, but the amount of imports in combination with the level of concentration in the domestic industry. That is in those industries in which there was a higher level of concentration as well as a low level of imports, the price-cost margin was higher, compared to an industry in which the level of concentration was high but the existence of a large quantity of competing imports weakened the impact of concentration on domestic profitability.

To take into account this interaction, the relationship between pricecost margin, imports and concentration was tested in the following form:

$$
(P C)_{i}=\alpha+b_{1}\left(C R_{4}\right)_{i}+b_{2}(K / O)_{i}+b_{3} M d C_{4}+e
$$

Where $(\mathrm{PC})_{\mathrm{i}}=$ Price-cost margin of the ith industry. 
$\left(\mathrm{CR}_{4}\right)_{\mathrm{i}}=$ Four-firm concentration ratio of the ith industry.

$(\mathrm{K} / \mathrm{O})_{\mathrm{i}}=$ Capital-output ratio of the ith industry.

Md = Dummy variable for competing imports i.e. $M d=1$ when imports are less than 20 per cent of total domestic sales, otherwise $\mathbf{M d}=0$.

$\mathrm{e}=$ error term.

TABLE 4

PRICE-COST MARGINS, CONCENTRATION AND FOREIGN COMPETITION

\begin{tabular}{lccccc}
\hline $\begin{array}{l}\text { Dependent } \\
\text { Variable } \\
(P C)\end{array}$ & $\begin{array}{c}\text { Concentra- } \\
\text { tion Ratio } \\
\left(C R_{4}\right)\end{array}$ & $\begin{array}{c}\text { Capital- } \\
\text { Output Ratio } \\
(\mathrm{K} / O)\end{array}$ & $\begin{array}{c}\text { Foreign Competition } \\
\text { (Concentration X } \\
\text { Dummy Variable) }\end{array}$ & $\begin{array}{c}\text { Constant } \\
\text { Term }\end{array}$ & $\boldsymbol{R}^{\mathbf{2}}$ \\
\hline $1965 / 66$ & $0.32^{\mathrm{a}}$ & -2.86 & $0.17^{\mathrm{b}}$ & 9.74 & 0.31 \\
& $(3.394)$ & $(1.094)$ & $(2.469)$ & & \\
$1966 / 67$ & $0.25^{\mathrm{a}}$ & 0.16 & $0.10^{\mathrm{b}}$ & 9.49 & 0.36 \\
& $(3.120)$ & $(0.005)$ & $(1.712)$ & & \\
$1967 / 68$ & $0.24^{\mathrm{a}}$ & -3.32 & 0.03 & 11.14 & 0.32 \\
& $(2.837)$ & $(0.686)$ & $(0.514)$ & & \\
$1969 / 70$ & $0.39^{\mathrm{a}}$ & -0.70 & 0.07 & 6.23 & 0.53 \\
& $(4.252)$ & $(0.158)$ & $(1.104)$ & & \\
Av. 4 Years & $0.30^{\mathrm{a}}$ & -0.06 & $0.10^{\mathrm{a}}$ & 8.64 & 0.61 \\
& $(5.316)$ & $(0.032)$ & $(2.520)$ & & \\
\hline
\end{tabular}

a: significant at the 1 per cent level.

b: significant at the 5 per cent level.

c: significant at the 10 per cent level.

Note: Figures in parentheses are t-ratios.

The results are given in Table 4 and the $\left(M_{d} C R_{4}\right)$ variable is significant in three of the five cases. It is significant at the five per cent level for 1965/66 and 1966/67 and at the one per cent level for the average of the four years. In testing the impact of competing imports on domestic profitability the best results are obtained when we combine the level of imports with the level of concentration existing in the domestic industry. However, our results on the whole suggest that although competing imports do have an inverse association with domestic profitability their impact is not as strong as we might have expected.

\section{Imports and Domestic Profitability: An Alternative Explanation}

One important reason for this could be the existence of a very strong linkage between the traders and the industrialists in Pakistan. It is well known that most of the industrialists especially the big industrial houses were originally traders who moved into industry following the collapse of the Korean boom and the imposition of tariffs on the imports of manufactured goods [see Papanek, 1967; Amjad, 1974]. Most of the industrialists in fact continued to have large interests in trade and the manner in which the import trade in Pakistan was regulated through entitlements to import licences on the basis of performance in the Korean boom i.e. 'category holders' meant that they continued to have 
virtual monopoly in the import trade. To quote from the Report of the Anti-Cartel Law Study Group [1965; 55],

The categorisation of imports is another important source of concentration of wealth and economic resources in a few hands in this country. Industrial category holders mostly got their categories fixed on the basis of an industrial survey carried out in 1955 . As far as commercial category holders are concerned their entitlement is based on their performance during the Korean boom period. To the extent that our import trade is regulated in accordance with the entitlement of category holders on the basis of past performance, newcomers are kept away.

An idea of the position of category holders in the import trade ${ }^{7}$ can be had from Table 5 showing the position in the period January-June 1963. (The figures are for actual imports).

TABLE 5

POSITION OF CATEGORY HOLDERS IN DMPORT TRADE JANUARY-JUNE 1963

$\begin{array}{cc}\text { Import Values } & \text { Percentage of } \\ \text { (Rs. Crores) } & \text { Total }\end{array}$

Category Holders (Total)

(i) Commercial

(ii) Industrial consumers

Open General Licence

$\left(\right.$ O.G.L.) ${ }^{8}$

Bonus Vouchers 9

$\left.\left.\begin{array}{c}16.87 \\ 40.21 \\ 6.44\end{array}\right\} 57.08 \quad \begin{array}{c}23 \% \\ 56 \% \\ 9 \%\end{array}\right\} 79 \%$

$9 \cdot 19$

$12 \%$

TOTAL

$72 \cdot 7$

$100 \cdot 0$

Source: Chief Controller of Imports \& Exports. [Report of the Anti-Cartel Law Study Group 1965, pp. 56]

It could be argued, however, that the influence of monopoly in the import trade was considerably reduced with the 'liberalisation'10 of the import trade especially through the introduction of the 'Free List' in 1963/64 according to which items placed on this list could be imported without having to apply for an import licence. In 1963/64 imports on the free list accounted for only fifteen per cent of total regulated imports but by 1964/65 this had increased to almost fifty per cent [see Report of the Working Group on Import Policy, 1967]. This policy of import liberalisation, however, suffered a severe setback when, after the war with India in September 1965, the country faced a foreign exchange crisis (because of foreign aid suspension and increase in defence imports) and items on the free list were considerably reduced and those on it were also subject to varying and increasing degree of administrative restrictions. During the period covered by our study, therefore, governments' efforts to liberalise imports were severely curtailed.

Even during the period of import liberalisation, studies carried out to see its impact found that it had made very little difference to the domestic prices of imported goods. In his first study, ${ }^{11} \mathrm{Pal}$ had found that there was no significant difference in profit margins between items imported by category holders and those on the Open General Licence 
[Pal, 1964: 605]. In his subsequent study he analysed price changes of commodities placed on the Free List and found that while prices of some had fallen, others had not been affected and some had in fact risen. On the weighted average of price of goods now placed on the Free List he found a very small decline [Pal, 1965: 550]. He also found that the increased supply effect of the Free List was insufficient to eliminate super normal profits ${ }^{12}$ and he explained this as being either due to the 'existence of monopolistic elements in the market' [Pal, 1965: 551] or because of administrative and other restrictions.

It should be pointed out, however, that the discussion so far is not to suggest that supply restrictions on imports are not an important factor in determining domestic prices and hence influencing profitability amongst different industries. What I am suggesting is that in so far as there is monopoly in the import trade (a point which they also emphasise) as well as a linkage between traders and domestic producers of the same commodity, imports will not act as a check on domestic profits for these imports are not competitive. Also the greater the monopoly in the import trade and the closer the linkage between the importers and the producers the less would be its impact. That this linkage existed can be seen by the fact that almost all the major industrialists had very large trading interests and were active importers [see Report of the Anti-Cartel Law Study Group, 1965, pp. 19].

An extreme example of this linkage and how it effected domestic profits is the sugar crises in the Winter of 1968. The extremely high profits in the sugar industry generated in the earlier years of the sixties was beginning to decline because of increased domestic production as well as new entrants into the industry [see Haq \& Baqai, 1967; Amjad, 1973]. By 1968 overproduction became a distinct possibility and there is evidence that sugar producers deliberately cut back production in order to keep sugar scarce and maintain or even raise domestic prices [see Pakistan Times, May 25, 1968]. The government responded to the situation by allowing the imports of sugar into the country. This should have resulted in lowering the prices. But it so turned out that of the five main importers, three were sugar producers themselves. ${ }^{13}$ This way, by holding the imported sugar back and not releasing it on to the market, they were able to keep sugar scarce and keep prices high. ${ }^{14}$ So that for $1968 / 69$ you would find that sugar industry profits were high although it was a year in which large amounts of imported sugar were entering the country. Any attempt to establish a negative relationship between imports and profits in this case would be highly unsuccessful.

\section{Impact of Capacity Utilisation on Price-Cost Margins}

To test the relationship between price-cost margins and concentration further we added capacity utilisation to our original model and tested it in the following form:

$$
(P C)_{i}=\alpha+b_{1}\left(C_{4}\right)_{i}+b_{2}(K / O)_{i}+b_{3}(C U)_{i}+e
$$

Where $(\mathrm{PC})_{\mathrm{i}}=$ Price-cost margin of the ith industry.

$\left(\mathrm{CR}_{4}\right)_{\mathrm{i}}=$ Four-firm concentration ratio of the ith industry. 
$(\mathrm{K} / \mathrm{O})_{\mathrm{i}}=$ Capital/output ratio of the ith industry.

$(\mathrm{CU})_{\mathrm{i}}=$ Capacity utilisation of the ith industry.

$\mathrm{e}=$ error term.

Theoretically we would expect there to be a strong and positive relationship between profitability and capacity utilisation. Other things remaining equal the higher the level of capacity utilisation the lower would be costs, especially the fixed cost component as it is spread over a greater number of units of production. Also to the extent that lower levels of capacity utilisation reflect a slackening of demand it could also be associated with lower prices in relation to costs at full capacity. Sawhney and Sawhney [1973] in their study on India had found capacity utilisation significantly and positively related to price-cost margins.

Islam [1967] in his study on Pakistan had however, come to quite the contrary result and had found 'excess profits'15 amongst different industries to be negatively related with capacity utilisation. ${ }^{16} \mathrm{He}$ had explained his rather surprising result by arguing that with a larger output firms tend to charge a lower profit margin, since a lower profit margin on a larger output may still lead to larger absolute profits, and more important to a higher return on capital. However, Islam had cautioned that, because of the small magnitude of the correlation coefficient between excess profits and capacity utilisation, the fall in 'excess' profits in response to a given change or increase in capacity utilisation is very small [Islam, 1967: 232].

The basic source of data used on capacity utilisation is the C.S.O. Survey [1965] and these figures were adjusted for certain industries from the World Bank Report [I.B.R.D., 1970] which gives more reliable estimates.

TABLE 6

PRICE-COST MARGNS, CONCENTRATION AND CAPACTTY UTILISATION

\begin{tabular}{cccccc}
\hline $\begin{array}{c}\text { Price-Cost } \\
\text { Margins }(P C) \\
\text { (Dependent } \\
\text { Variable) }\end{array}$ & $\begin{array}{c}\text { Concen- } \\
\text { tration } \\
\text { Ratio } \\
\left(C R_{4}\right)\end{array}$ & $\begin{array}{c}\text { Capital- } \\
\text { Output } \\
\text { Ratio } \\
(K / O)\end{array}$ & $\begin{array}{c}\text { Capacity } \\
\text { Utilisa- } \\
\text { tion } \\
(C U)\end{array}$ & $\begin{array}{c}\text { Constant } \\
\text { Term }\end{array}$ & $R^{2}$ \\
\hline $1965 / 66$ & $0.18^{\mathrm{b}}$ & -2.99 & 0.07 & 7.21 & 0.20 \\
& $(2.205)$ & $(0.920)$ & $(0.762)$ & & \\
$1966 / 67$ & $0.21^{\mathrm{b}}$ & -1.27 & $0.14^{\mathrm{b}}$ & -0.61 & 0.35 \\
& $(2.732)$ & $(0.409)$ & $(1.759)$ & & \\
$1967 / 68$ & $0.22^{\mathrm{a}}$ & -4.76 & 0.05 & 8.30 & 0.32 \\
& $(4.375)$ & $(0.998)$ & $(0.598)$ & & \\
$1969 / 70$ & $0.37^{\mathrm{a}}$ & -4.14 & $0.22^{\mathrm{a}}$ & -8.73 & 0.64 \\
& $(5.605)$ & $(1.054)$ & $(2.894)$ & & \\
Av. 4 Years & $0.24^{\mathrm{a}}$ & -2.38 & $0.11^{\mathrm{b}}$ & 2.45 & 0.57 \\
& $(4.813)$ & $(0.876)$ & $(1.925)$ & & \\
\hline
\end{tabular}

a: significant at the 1 per cent level.

b: significant at the 5 per cent level.

c: significant at the 10 per cent level.

Note: Figure in parenthesis are t-ratios. 
The results of our model showed that capacity utilisation was positively related with price-cost margins for all the years but was significant only in three cases - for $1969 / 70$ at the one per cent level and for 1966/67 and the average of the four years at the five per cent level.

Our results therefore seem to support to some extent the hypothesis of a positive and significant relationship between price-cost margins and capacity utilisation and are contrary to Islam's [1967] findings of a negative relationship between these two variables which depends crucially on the assumption that firms with higher capacity utilisation tend to pass on reduction in costs in terms of lower prices and hence lower profit margins.

\section{CONCLUSIONS}

We set out in this paper to test the impact of concentration on profitability in the large-scale manufacturing sector in West Pakistan for the years between 1965 and 1970 . Our sample comprised of twenty-five industries and covered over eighty per cent of the large-scale manufacturing sector. The main results were (a) When price-cost margins are used as an indicator of profitability, concentration was an important factor in explaining differences in profitability between different industries. (b) Profitability was not significantly related to capital-output ratios. (c) Although the impact of foreign competition on profitability is significant, it is not as strong as earlier studies on Pakistan might lead us to believe. This may originate from the linkage between the industrial and trading interests, a product of historical circumstances in the country. In fact it is interesting to note that imports worked best as an explanatory variable when it was specified in an interaction term with concentration, and suggests that a lot of arguments connecting imports and profitability cannot be carried out without taking into account the effects of concentration. (d) Price-cost margins in three of the five years studied was positively and significantly related to capacity utilisation.

\section{NOTES}

1. The Cartel Law Study Group [1965] set up in 1963 to investigate 'business malpractices, the higher prices charged and exploitation of consumers', submitted its report in 1965 but it was never made public and has only recently been made available for very limited circulation.

2. M. Haq was then Chief Economist of the Planning Commission.

3. These industries were cotton textiles, jute textiles, artificial silk textiles, sugar, vegetable ghee, tea blending, paper, leather tanning, motor vehicles, chemicals, petroleum products, cement, other non-metallic minerals, basic metals, metal products, nonelectrical machinery and electrical machinery.

4. In the case of the jute industry in W. Pakistan production did not start till 1968/69 and was therefore completely left out. According to the Census of Manufacturing Industries 1964/65 (the last complete Census for both wings of the country available), 70 per cent of paper and paper products production was in E. Pakistan and 100 per cent for tea manufacturing. (Breakdown of tea blending production was not given because of problems of firms identification.)

5. For their calculation of the rates of protection Lewis \& Guisinger relied heavily on Pal's two surveys carried out in 1963/4 and 1964/5. In his surveys Pal had collected data on domestic prices of commodities from wholesalers and purchasers of goods and the c.i.f. prices of identical commodities from custom records. This is an extremely difficult task 
especially in trying to find 'identical' goods and differentiating for different grades or sizes of items. [For details of how this survey was carried out see Pal, 1964 and 1965.] In the case of a few other industries Lewis and Guisinger used direct comparisons between domestic and 'world' prices which again involves making a number of assumptions in finding identical goods. [See Lewis \& Guisinger, 1971, Appendix E: 362-3 for details of how their different rates of protection were worked out.]

6. After the collapse of the Korean boom and the cessation of imports on the open general licence system the government decided to distribute licences for future imports only to those firms who had been importers during the $2 \frac{1}{2}$ years i.e. July 1950 to November 1952 prior to the imposition of controls. These importers came to be called 'category holders' or 'established importers' and the policy was referred to as the 'category system' [see Thomas 1966].

7. This is the total regulated import trade and accounts for about fifty per cent of the total imports into the country and about seventy per cent of total private imports. Other private imports not covered by this are either imports of machinery under foreign credits or imports under the Indus basin project.

8. The O.G.L. was introduced in 1961 and it applied to specific commodities and to specific group of commercial importers and provided for issue of licences of specified amount in each shipping period. Its purpose was to encourage new entrants in the import trade and to extend the value of licences issued in the commodities chosen.

9. Import licences were also issued under the Export Bonus Scheme on the basis of import bonus vouchers issued by the State Bank of Pakistan to exporters for a specified part of their foreign exchange earnings. Imports allowed under bonus voucher are specified in the 'bonus list' in the import policies [see Bruton \& Rose, 1963].

10. Import 'liberalisation in the Pakistan context has been defined by Thomas [1966] as 'changes in import policy placing greater reliance on market mechanism in allocating foreign exchange'.

11. The problems mentioned earlier in calculating the rates of protection by Lewis \& Guisinger based on Pal's survey are not applicable here as in this case data regarding the change of prices of the same commodity was being collected from the same source.

12. Pal took the 'normal' mark-up as twelve per cent which was taken from the Tariff Commission. The weighted average of margins on items on the Free List was twenty-eight per cent [Pal, 1965: 551].

13. The then Commerce Minister Mr. Hoti (incidently also an owner of one of the largest sugar mill in the country) accused some manufacturers of having joined hands with 'importers' - in fact some of the principal importers were also manufacturers - to inflate sugar prices artificially to the detrement of consumers. Replying to a question the Minister said that the five big traders were the manipulators-Adamjee*, Bawany*, Haji Hashim, Mian Bashir* and Abed. [Reported in the Pakistan Times-Dec. 16th, 1968].( ${ }^{*}$ owned sugar mills).

14. A report in the Observer [6th Dec. 1968] entitled 'Sugar Crisis' stated that, 'The crux of the matter is that mills took loans up to 75 per cent of stock value which helped them to hold back stocks.'

15. Excess profits was defined as the difference between the actual and 'normal' price expressed as a ratio of the actual price. It was used in the sense of an abnormal mark-up in the excess over the 'normal' or 'fair' mark up on ex-factory prices as used by the Tariff Commission [Islam, 1967: 231].

16. Islam's study was based on 115 industries and covered a fifteen year period 1951-66. However, it excluded certain important industries such as cotton textiles, jute textiles, woollen textiles, and fertiliser, machinery and transport equipment as they were not investigated by the Tariff Commission, the source of data for his study.

\section{REFERENCES}

Amjad, R., 1974, Industrial Concentration and Economic Power in Pakistan, (South Asian Institute, Punjab University, Lahore).

Amjad, R., 1973, 'Growth, Profitability and Savings of Quoted Companies 1964-70', Pakistan Economic and Social Review, Vol. XI, No. 4, December 1973.

Benishay, N., 'Concentration and Price-Cost Margins: A Comment', Joumal of Industrial Economics, November 1967, 1973-74. 
Bruton, H. J., and Bose, S. R., 1963, 'The Pakistan Export-Bonus Scheme', Monograph 11, Pakistan Institute of Development Economics, Karachi 1963.

Collins, N., and L. Preston, 1968, Concentration and Price-Cost Margins in Manufacturing Industries, (University of California Press, Berkeley).

Dawn, Karachi, English Daily.

Fazili, M. A., 1969, Pharmaceutical Industry in West Pakistan, Directorate of Industries, Government of West Pakistan.

Govt. of Pakistan, 1967, Report of the Working Group on Import Policy, Ministry of Commerce (1967).

Govt. of Pakistan, 1965, Report of the Anti-Cartel Study Group.

Govt. of Pakistan, Census of Manufacturing Industries (1965/66, 1966/67 and 1969/70) (Central Statistical Office).

Govt. of Pakistan, Summary Statistics of Census of Manufacturing Industries 1967/68, Monthly Statistical Bulletin Vol. 20, No. 5, May 1972 (Central Statistical Office).

Govt. of Pakistan, Monthly Statistical Bulletin, Central Statistical Office.

Govt. of Pakistan, Report of Survey on Capacity Utilisation by Manufacturing Industries 1965, (Central Statistical Office).

Govt. of Pakistan, Directory of Industrial Establishments in Pakistan Vol. I to III, (1972) (Department of Investment Promotion and Supplies, Karachi.)

Govt. of West Pakistan, Directory of Industrial Establishments in W. Pakistan, (March 1969).

Haq, K., and M. Baqai, 1967, 'Savings and Financial Flows in the Corporate Sector, 195963', Pakistan Development Review, Vol. III, No. 3, Autumn 1967.

Hazari, K., 1966, Corporate Private Sector, Bombay, Asia Publishing House.

Holterman, S., 1973, 'Market Structure and Economic Performance in U.K. Manufacturing Industries', Joumal of Industrial Economics, Vol. XXII, No. 2, 1973.

Islam, N., 1967, 'Comparative Costs, Factor Proportions and Industrial Efficiency in Pakistan', Pakistan Development Review, Vol. VII, No. 2, Summer 1967.

International Bank for Reconstruction \& Development, 1970, Industrialisation of Pakistan, Vol. II, March 1970.

Jafri, S. J., 1969, Woollen and Worsted Industry in West Pakistan, Directorate of Industries, Govt. of West Pakistan.

Khalilzadeh, S. J., 1974, 'Market Structure and Price-Cost Margins in the United Kingdom Manufacturing Industries', Review of Economics \& Statistics, Vol. VI, No. 1, 1974.

Lewis, S. R., 1970, Pakistan-Industrialisation and Trade Policies, (Oxford University Press).

-Lewis, S., and S. E. Guisinger, 1971, The Structure of Protection in Pakistan in The Structure of Protection in Developing Countries, Bela Balassa ed. Baltimore (Johns Hopkins Press).

Mehrav, M., 1969, Technological Dependence, Monopoly and Growth, New York, Pergamon Press, 1969.

Observer, Dacca, English Daily.

Ornstein, S. I., 'Empirical Uses of the Price-Cost Margin', Joumal of Industrial Economics, Vol. XXIV, No. 2, December 1975.

Pal, M., 1964, 'The Determinants of the Domestic Price of Imports', Pakistan Development Review, Vol. IV, No. 4, Winter 1964.

Pal, M., 1965, 'Domestic Prices of Imports in Pakistan, Extension of Empirical Findings', Pakistan Development Review, Vol. V, No. IV, Winter 1965.

Pakistan Times, Lahore and Rawalpindi, English Daily.

Papanek, G. F., 1967, Pakistan's Development-Social Goals and Private Incentives, Cambridge Mass: Harvard University Press.

Sawhney, P., and B. Sawhney, 1973, 'Capacity Utilisation, Concentration and Price-Cost Margins: Results on Indian Industries', Journal of Industrial Economics, Vol. XXI, No. 2, 1973.

Schwartzmen, D., 1959, 'The Effect of Monopoly on Price', Journal of Political Economy, Vol. LXVII-No. 4, August, 1959.

Shibli, A. R., 1972, The Twenty-Two Families, People Publishing House, Lahore, (in Urdu).

Winston, G. C., 1968, Excess Capacity in Underdeveloped Countries: the Pakistan Case, 
Research Memorandum, No. 25, Centre for Development Economics, Williams College, Sept., 1968.

White, L. J., 1974a, 'Pakistan's Industrial Families', Joumal of Development Studies, Vol. 10, Nos. 3 and 4, 1974.

White, L. J., 1974b, Industrial Concentration and Economic Power in Pakistan, Princeton University Press.

\section{APPENDIX}

\begin{tabular}{|c|c|c|c|c|}
\hline Industry & $\begin{array}{c}\text { Price-Cost } \\
\text { Margin * } \\
\text { (Av. } 4 \text { years) }\end{array}$ & $\begin{array}{c}\text { Four-Firm } \\
\text { Concentration } \\
\text { Ratios }\end{array}$ & $\begin{array}{c}\text { Capital-Output } \\
\text { Ratio* } \\
\text { (Av. } 4 \text { years) }\end{array}$ & $\begin{array}{c}\text { Capacity } \\
\text { Utilisation }\end{array}$ \\
\hline 1. Grain Milling & $3 \cdot 8$ & $11 \cdot 0$ & $0 \cdot 12$ & $100 \cdot 0$ \\
\hline 2. Sugar & $23 \cdot 3$ & $33 \cdot 7$ & 0.81 & $92 \cdot 4$ \\
\hline 3. Edible oils & $8 \cdot 5$ & $20 \cdot 5$ & $0 \cdot 21$ & $65 \cdot 0$ \\
\hline \multicolumn{5}{|l|}{ 4. Drinks and carbonated } \\
\hline water & $18 \cdot 7$ & $70 \cdot 0$ & 0.89 & $100 \cdot 0$ \\
\hline 5. Cigarettes & $40 \cdot 3$ & $79 \cdot 7$ & $0 \cdot 22$ & $83 \cdot 1$ \\
\hline 6. Cotton spinning & $17 \cdot 4$ & $30 \cdot 0$ & $0 \cdot 74$ & $90 \cdot 1$ \\
\hline 7. Wool spinning & $23 \cdot 1$ & $65 \cdot 2$ & 0.84 & $100 \cdot 0$ \\
\hline 8. Silk \& Art silk & $15 \cdot 2$ & $10 \cdot 0$ & 0.41 & $59 \cdot 0$ \\
\hline 9. Dyeing \& Bleaching & $14 \cdot 2$ & $7 \cdot 4$ & 0.62 & $82 \cdot 3$ \\
\hline 10. Rubber Footwear & $19 \cdot 1$ & $67 \cdot 1$ & $0 \cdot 31$ & 79.6 \\
\hline 11. Books \& Periodicals & $26 \cdot 6$ & $30 \cdot 0$ & 0.60 & $100 \cdot 0$ \\
\hline 12. Tanning \& Leather & $21 \cdot 3$ & $40 \cdot 0$ & $0 \cdot 12$ & 56.9 \\
\hline 13. Cotton Ginning & $\mathbf{7 \cdot 8}$ & $7 \cdot 0$ & $0 \cdot 10$ & $87 \cdot 3$ \\
\hline 14. Cement & $27 \cdot 3$ & $67 \cdot 0$ & $1 \cdot 74$ & $100 \cdot 0$ \\
\hline 15. Tyres \& Tubes & $31 \cdot 9$ & $90 \cdot 0$ & $0 \cdot 60$ & $98 \cdot 5$ \\
\hline 16. Fertiliser & $31 \cdot 7$ & $100 \cdot 0$ & $2 \cdot 5$ & $77 \cdot 6$ \\
\hline 17. Paints \& Varnishes & $22 \cdot 0$ & $52 \cdot 4$ & 0.27 & $40 \cdot 0$ \\
\hline 18. Pharmaceuticals & $28 \cdot 5$ & $44 \cdot 8$ & $0 \cdot 30$ & $53 \cdot 8$ \\
\hline \multicolumn{5}{|l|}{ 19. Products of Petroleum } \\
\hline \& Coal & $43 \cdot 1$ & $100 \cdot 0$ & 0.45 & $100 \cdot 0$ \\
\hline 20. Acids, Alkalies \& salts & $22 \cdot 0$ & $100 \cdot 0$ & 1.69 & 53.4 \\
\hline 21. Iron \& steel & 16.9 & 45.9 & $\mathbf{0} \cdot 30$ & $42 \cdot 5$ \\
\hline \multicolumn{5}{|l|}{ 22. Motors, Generators \& } \\
\hline Transformers & $28 \cdot 7$ & $74 \cdot 5$ & $0 \cdot 38$ & $55 \cdot 0$ \\
\hline \multicolumn{5}{|l|}{ 23. Communication equip- } \\
\hline ment & $20 \cdot 8$ & $90 \cdot 0$ & 0.62 & $44 \cdot 3$ \\
\hline 24. Mechanical vehicle & $18 \cdot 6$ & $80 \cdot 0$ & $0 \cdot 33$ & $24 \cdot 3$ \\
\hline 25. Engines \& Turbines & $18 \cdot 6$ & $62 \cdot 3$ & 0.59 & 29.1 \\
\hline
\end{tabular}

Sounces: (See text)

- Data for the individual years are available with the author and can be obtained from him on request. 